\title{
Prevalence and intensity of occurrence of vaterite inclusions in aragonite otoliths of American eels Anguilla rostrata
}

\author{
B. M. Jessop ${ }^{1, *}$, J. C. Shiao ${ }^{2}$, Y. Iizuka ${ }^{3}$, W. N. Tzeng ${ }^{4,5}$ \\ ${ }^{1}$ Department of Fisheries and Oceans, Bedford Institute of Oceanography, PO Box 1006, Dartmouth, Nova Scotia B2Y 4A2, Canada \\ ${ }^{2}$ Institute of Oceanography, ${ }^{4}$ Department of Life Science and ${ }^{5}$ Institute of Fisheries Sciences, College of Science, \\ National Taiwan University, Taipei, Taiwan 10617, ROC \\ ${ }^{3}$ Institute of Earth Sciences, Academia Sinica, Nankang, Taipei, Taiwan 11529, ROC
}

\begin{abstract}
The presence of vaterite mosaic in the aragonite otoliths of anguillid eel otoliths is readily determined by reflected light microscopy after etching with EDTA. The prevalence and intensity of vaterite inclusions in sagittal otoliths of 165 American eels Anguilla rostrata were examined in relation to latitude and migratory history. Prevalence varied significantly (range: 21.3 to $58.8 \%$ ) among 3 rivers in Atlantic Canada and increased non-linearly with latitude. Habitat differences among sites may confound the relation because most (48\%) vateritic otoliths came from eels with a history of estuarine residence and inter-habitat migration. The limited number of sites, restricted geographic range and modest otolith sample sizes makes premature any conclusion that the prevalence of vateritic otoliths in American eels increases with latitude. The frequency of vaterite inclusions in otoliths $(\mathrm{n}=63)$ was low ( 1 to 6$)$ and did not vary among sites. Vaterite intensity was low $(<5 \%$, median $=0.21 \%$, over all sites after excluding 7 outliers $[11.1 \%$ of vaterite group] ranging to $37 \%$ vaterite content). Mean intensity varied significantly among sites, but the means are trivially low and of no practical consequence. Mean Sr:Ca concentration ratios were much lower (10 to $17 \%)$ in vaterite than in aragonite, leading to possible misidentification of habitat residence and migratory history, particularly for eels resident in saline waters. The presence of vaterite in anguillid eel otoliths is not an impediment to the use of microchemical analysis methods provided that vaterite inclusions are identified and avoided so as to prevent potentially serious misidentification of habitat residence and inter-habitat migratory history.
\end{abstract}

KEY WORDS: American eel $\cdot$ Otoliths $\cdot$ Vaterite $\cdot$ Prevalence $\cdot$ Intensity

\section{INTRODUCTION}

The migratory history of anguillid eels and other fishes between habitats of varying salinity has been evaluated in recent years by examination of the concentration ratios of strontium (Sr) to calcium (Ca) along a transect from the core to the edge of sagittal otoliths (e.g. Tzeng et al. 1997, 2002, Jessop et al. 2002, 2007, 2008, Elsdon \& Gillanders 2003, Daverat et al. 2006). Otoliths are primarily composed of $\mathrm{CaCO}_{3}$, with a minor organic matrix, and are metabolically inert once deposition has occurred (Degens et al. 1969). The daily and seasonally rhythmic deposition of otolith increments (Pannella 1971), which incorporates at least 31 elements, often in proportion to their ambient concentrations in the aquatic habitat, permits the subsequent evaluation of the environmental history of the fish (Campana 1999). The use of Sr:Ca ratios in otoliths to examine the environmental history of a fish requires assumptions about the effects of 4 major factors: (1) environmental variable influence on otolith chemistry, (2) exposure time to environmental variables on the 
incorporation of elements into otoliths, (3) fish ontogeny and age structure on migratory reconstruction, and (4) analytical methods used to infer environmental histories (Elsdon \& Gillanders 2003).

The incorporation of elements into otoliths is a complex biogeochemical process influenced by ambient water chemistry (Campana 1999), fish ontogeny and physiology (Kalish 1989, Tzeng 1996), and otolith crystal structure (Brown \& Severin 1999, Melancon et al. 2005, Tzeng et al. 2007). Otoliths typically consist of aragonite, 1 of 3 natural polymorphs of $\mathrm{CaCO}_{3}$ (calcite, aragonite and vaterite), but may also form inclusions of vaterite that differ in elemental composition from aragonite (Gauldie 1986, Tomás \& Geffen 2003, Tzeng et al. 2007). The prevalence of vateritic otoliths varies among fish species (Bowen et al. 1999, Brown \& Severin 1999, Tomás \& Geffen 2003, Tzeng et al. 2007), but intensity of occurrence is rarely reported (e.g. Bowen et al. 1999). The prevalence of vateritic otoliths has, for cultured species, been correlated with stress factors such as high density, temperature fluctuation, disease and poor water quality (Sweeting et al. 2004). Little is known about the causes of vateritic otoliths in wild fishes, whether the prevalence and intensity of vaterite inclusions varies geographically for a species, or is influenced by life-history factors such as life stage, residence habitat and migratory history.

The accurate classification of the habitat residence and historic migratory behaviour of anguillid eels by otolith Sr:Ca ratios depends upon the identification and avoidance of vaterite inclusions, which differ in chemical composition from aragonite. Vaterite $\mathrm{Sr}: \mathrm{Ca}$ ratios are much lower than those of aragonite and could be confused with freshwater residence and thus result in the misidentification of habitat use and historic migratory behaviour (Tomás \& Geffen 2003, Tzeng et al. 2007). This study examines: (1) the prevalence and intensity of occurrence of vaterite inclusions in aragonite otoliths of American eels Anguilla rostrata from 3 rivers in Atlantic Canada and (2) their relation to latitude and migratory history group, and (3) evaluates the effect of vaterite inclusions on otolith $\mathrm{Sr}: \mathrm{Ca}$ ratio analysis used to estimate the percentage of time eels are resident in freshwater $(\% \mathrm{fwg}$; Jessop et al. 2007).

\section{MATERIALS AND METHODS}

Data for the present study were obtained from the sagittal otoliths of American eels Anguilla rostrata collected from the East River, on the Atlantic coast of Nova Scotia (latitude $44^{\circ} 35^{\prime} 16^{\prime \prime} \mathrm{N}$ ) and the estuary of Flat Bay Brook (latitude $48^{\circ} 24^{\prime} 27^{\prime \prime} \mathrm{N}$ ) and the Castors River (latitude $50^{\circ} 55^{\prime} 15^{\prime \prime} \mathrm{N}$ ) on the western coast of
Newfoundland (Fig. 1). These sites represent a large portion of the geographic range of American eels in Atlantic Canada, which contains the northern limit of a continental range that extends to northern South America (Scott \& Scott 1988). Silver eels were collected from the East River and Castors River, and yellow eels, from Flat Bay Brook during autumn commercial fisheries (see Table 1).

Otoliths $(\mathrm{n}=165)$ were examined by compound optical microscopy for the presence of vaterite following etching with $5 \%$ EDTA as described by Tzeng et al. (2007), who observed that vaterite appears dark under reflected light after EDTA etching and confirmed the identification of vaterite by Raman spectroscopy. The prevalence (percentage of the total number of samples from a site containing vaterite inclusions), frequency (number of inclusions per otolith) and intensity of occurrence (percentage [converted to proportion as necessary] of total otolith area occupied by inclusions of effectively measurable size) were estimated with image analysis software from calibrated otolith photographs. Ages were estimated by counting the annuli (translucent zones under reflected light), as in previous studies (e.g. Jessop et al. 2002). Otolith Sr:Ca ratios (weight percent, wt\%) were measured from the primordium to the edge at $10 \mu \mathrm{m}$ intervals by an electron probe microanalyzer (EPMA, JEOL, JXA-8900R) as described by Tzeng et al. (1997) and Jessop et al. (2002). Single otolith Sr:Ca transects from the primordium to

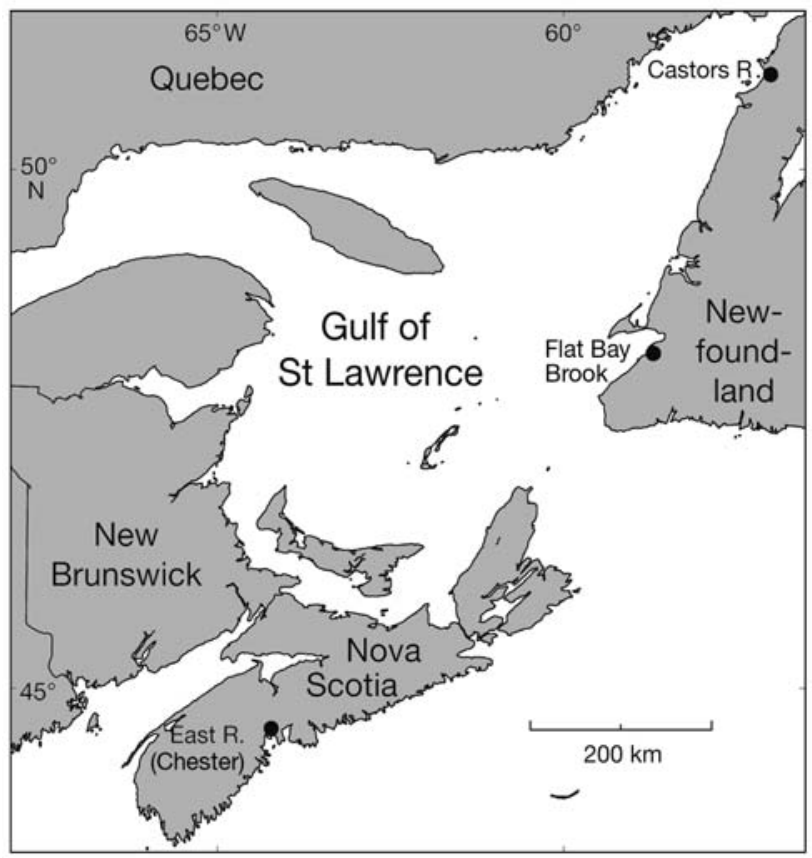

Fig. 1. Map of American eel sampling sites in eastern Canada. The distance between East River (Chester) and Castors River is about $870 \mathrm{~km}$ 
Table 1. Anguilla rostrata. Sample data for the analysis of microchemistry and prevalence (\%) of vaterite inclusions in otoliths of American eels from 3 rivers in Atlantic Canada; $\mathrm{n}$ : number of fish. Total length (TL) and age data are mean \pm SD. ER and CR: East and Castors Rivers, respectively; FBB: Flat Bay Brook; Prev.: Prevalence

\begin{tabular}{|lclcrc|}
\hline Site & $\mathrm{n}$ & Stage & TL $(\mathrm{mm})$ & Age (yr) & Prev. (\%) \\
\hline ER & 61 & Silver & $403.9 \pm 81.77$ & $16.4 \pm 3.96$ & 21.3 \\
FBB & 51 & Yellow & $434.3 \pm 80.99$ & $6.2 \pm 2.96$ & 58.8 \\
CR & 53 & Silver & $627.8 \pm 136.97$ & $19.0 \pm 6.50$ & 37.7 \\
\hline
\end{tabular}

edge of each otolith were oriented to avoid vaterite areas except for one case, where two additional transects were made through vaterite inclusions for comparison. The percent freshwater residence/growth (\%fwg) was estimated as the percentage of total $\mathrm{Sr}: \mathrm{Ca}$ ratio values $\leq 4.0 \times 10^{-3}$ from the elver check to the otolith edge (Jessop et al. 2006, 2007). The habitat transition criterion of $4.0 \times 10^{-3}$ determined for the East River, Chester (Jessop et al. 2002), was assumed, in the absence of contraindications, to apply to Flat Bay Brook and Castors River.

The prevalence of vaterite inclusions in otoliths was examined by contingency table and the G-test (likelihood ratio chi-squared; Sokal \& Rohlf 1981), with linear contrasts used to test specific hypotheses, e.g. whether one group differed significantly from another. The possibility of a linear trend in prevalence with increasing latitude was evaluated by Cochran's test of linear trend (Systat10, SPSS) and for a nonlinear (quadratic) trend by contrast.

The effect of migratory group (Migratory Groups [MGs] 1 to 4) on vaterite prevalence (sites combined) was examined by G-test, with MG 3 combined with MG 1 because of low cell size. Jessop et al. (2006) describe the MGs as:

Group 1: entrance to freshwater as an elver and remaining in freshwater until capture as a juvenile (yellow) eel.

Group 2: entrance to freshwater as an elver and remaining in the river for a variable number of years before returning to the estuary for a variable number of years and finally returning to the river before capture.

Group 3: entrance to freshwater as a juvenile after $\geq 1 \mathrm{yr}$ in the estuary, then remaining in the river until capture.

Group 4: entrance to freshwater as a juvenile after $\geq 1 \mathrm{yr}$ in the estuary, then remaining in the river for a variable number of years before returning to the estuary for a variable number of years and finally returning to the river before capture.

Migration groups can be further combined, with Groups 1 and 3 (combined) designated as non-migra- tory eels and Groups 2 and 4 (combined) designated as migratory eels.

The influence of percentage of freshwater residence/ growth (\%fwg), by site, on vaterite prevalence was examined by the analysis of variance (ANOVA), as were differences in the frequency and intensity of vaterite inclusions by site. Data on the frequency and intensity of vaterite inclusions were assessed for compliance with the requirements of parametric statistics, with frequency transformed by $-1 / \sqrt{Y}$, where $Y$ is frequency value, and intensity and \%fwg transformed by arcsine $\sqrt{p}$, where $p$ is the value as a proportion. The homogeneity of variances was evaluated by Levene's test (Wilkinson et al. 1996). Outliers in the distribution of vaterite intensity values at each site were determined by box plots, with outliers being values $>3$ times the interquartile range. The prevalence of vateritic otoliths among sites was examined by contingency table analysis, with effect size magnitudes measured, as appropriate, by ø (equivalent to Pearson's $r$ for binary data), where values of 0.1 are regarded as low; 0.3 as moderate; and 0.5 as large (Cohen 1988). Statistical significance was accepted at $\alpha=0.05$.

\section{RESULTS}

\section{Microscopic structure of vaterite}

Vaterite inclusions in American eels Anguilla rostrata appeared opaque when viewed under reflected light after etching with EDTA (Fig. 2C,D). The area, orientation and shape of vateritic inclusions varied among otoliths, and, in this example, the area was unusually large (24.2\% of otolith area), composed of 3 inclusions and located in the dorsal post-rostrum of the otolith. The annulus structure was typically clear in the aragonite portions of an otolith (Fig. 2A,B) and distorted and unclear in the vateritic portions.

\section{Vaterite effects on $\mathrm{Sr}$ :Ca ratio values}

Electron microprobe transects oriented so as to avoid vaterite inclusions (Fig. 2A,B) produced estimates of freshwater habitat residence different from those that crossed vaterite inclusions. Closely spaced radial transects that did not cross vaterite inclusions (Fig. 2A,B) were closely similar in patterns of $\mathrm{Sr}$ :Ca ratio values and produced similar estimates of freshwater residence ( $\%$ fwg $=9.0$ and 9.9; Fig. 3A,B), while transects crossing vaterite inclusions (Fig. 2C,D) produced greatly different estimates of freshwater residence $(\% \mathrm{fwg}=$ 73.2, 67.0; Fig. 3C,D), depending upon the proportion of vaterite along the transect. Within the vaterite areas, 


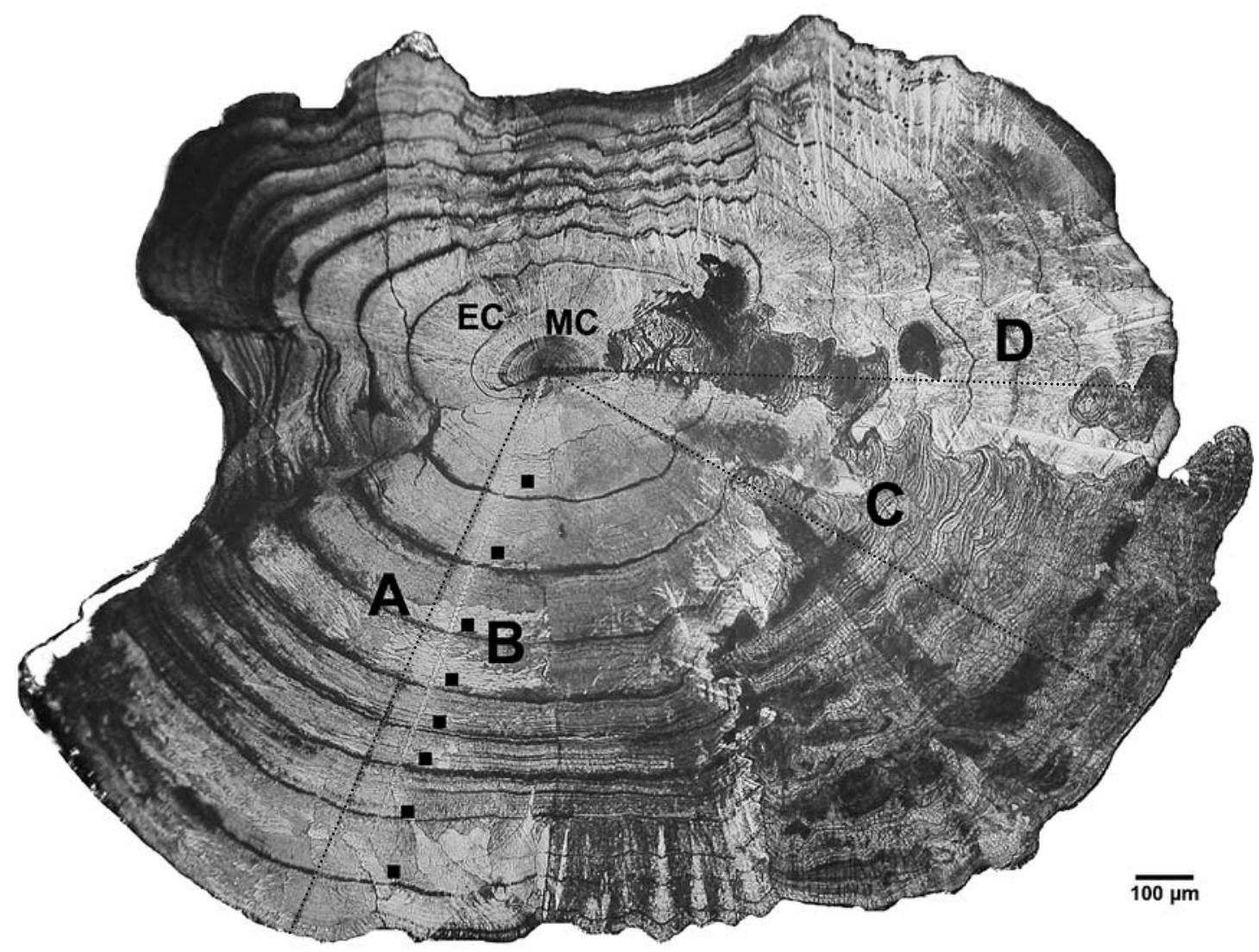

Fig. 2. Anguilla rostrata. Otolith of yellow American eel (449 mm total length, age $8 \mathrm{yr}$ ) showing electron microprobe transects for measuring Sr:Ca ratios: A and B: duplicate transects avoiding vaterite inclusions; C and D: transects across different vaterite areas. The vaterite areas to the right and lower right of the primordium are darker and have an indistinct annular structure. MC: metamorphosis check; EC: elver check; solid dots: annuli. Note: the annuli dots parallel microprobe transect B

Sr:Ca ratios averaged $0.63 \times 10^{-3}$ (Fig. 3 C) to $0.78-1.0 \times$ $10^{-3}$ (Fig. 3D), while, within aragonite, the Sr:Ca ratios averaged $6.62 \times 10^{-3}$ (Fig. 3C) and $5.88 \times 10^{-3}$ (Fig. 3D) Thus, Sr:Ca ratio values in aragonite were 5.8 to 10.5 times greater than in vaterite for an eel with a largely estuarine history. Sr:Ca ratio values in vaterite deposited while an eel is evidently in a saltwater habitat may be within the mid- to low range of values typically seen in aragonite for eels in a freshwater habitat (Fig. 3C,D). Sr:Ca ratio values in vaterite deposited while an eel is in a freshwater habitat are very low, often $<1.0 \times 10^{-3}$.

\section{Prevalence, intensity and frequency of occurrence of vaterite}

The prevalence of vaterite inclusions in the otoliths of American eels varied significantly among the 3 sites examined $(G=16.9$, df $=2, \mathrm{p}<0.001)$, ranging from $21.3 \%$ in East River to $58.8 \%$ in Flat Bay Brook (Table 1). Linear contrasts indicated that the prevalence of vaterite differed significantly between the
East River (21.3\%) and Castors River (37.7\%) $(Z=1.94$, $\mathrm{p}=0.026)$ and between Castors River and Flat Bay Brook $(58.8 \%)(Z=2.20, \mathrm{p}=0.014)$ and, by inference, between East River and Flat Bay Brook. A test of linear trend in the prevalence of vaterite inclusions with latitude (increasing from East River to Flat Bay Brook to Castors River) was marginally non-significant (Cochran's test of linear trend $=3.77$, df $=1, p=0.052$, $\varnothing=0.15$ ), but a contrast for nonlinear (quadratic) trend was highly significant $(Z=8.26, \mathrm{p}<0.0001, \varnothing=0.64)$, with Flat Bay Brook having a higher prevalence of vaterite inclusions relative to latitude.

Vaterite prevalence differed significantly among MGs (sites combined, $G=13.8$, df $=2, \mathrm{p}=0.001$ ), with MG 4 (53.4\%) significantly larger than MG 2 (29.6\%) $(Z=2.79, \mathrm{p}=0.003, \varnothing=0.24)$ and MG 2 not significantly different from MG $1+3(21.1 \%)(Z=0.95, \mathrm{p}=$ $0.17, \varnothing=0.10$ ) (Table 2). By inference, vaterite prevalence for MG $1+3$ was significantly smaller than for MG 4. Migratory eels (MG $2+$ MG 4 combined) had significantly more $(G=6.54$, df $=1, \mathrm{p}=0.010)$ vaterite otoliths than did non-migratory eels (MG $1+$ MG 3 combined), with $87.3 \%$ of vateritic otoliths occurring in 

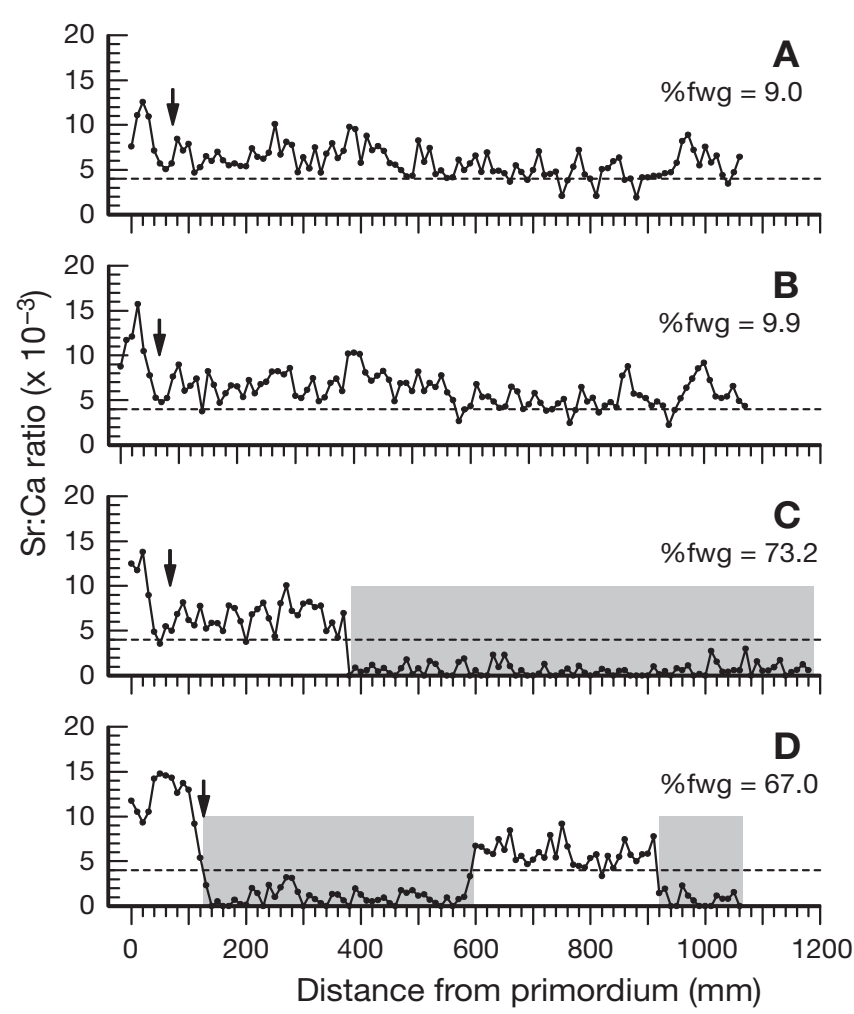

Fig. 3. Anguilla rostrata. (A to D) Plots of otolith Sr:Ca ratio data for electron microprobe transects A to D, indicating the effects of vaterite inclusions on $\mathrm{Sr}$ :Ca values. Arrows: elver check; dashed line: $4.0 \times 10^{-3}$ habitat transition criterion; \%fwg: percent of growth in freshwater; shaded areas of Panels (C) and (D): vaterite areas and false freshwater signal

Table 2. Anguilla rostrata. Prevalence (\%) of vaterite inclusions in otoliths of American eels by migratory group (total otoliths, $\mathrm{n}=165)$, and vateritic otolith distribution ( $\%$ of vateritic otoliths, $\mathrm{n}=63$ ) by site and migratory group

\begin{tabular}{|lccc|}
\hline & \multicolumn{3}{c|}{ Migratory group } \\
& $1+3$ & 2 & 4 \\
\hline Vaterite prevalence & & & \\
Prevalence & 21.1 & 29.6 & 53.4 \\
$\mathrm{n}$ & 38 & 54 & 73 \\
Distribution of vateritic otoliths & & \\
East River & 6.3 & 9.5 & 4.8 \\
Flat Bay Brook & 0 & 0 & 47.6 \\
Castors River & 6.3 & 15.9 & 9.5 \\
$\mathrm{n}$ & 8 & 16 & 39 \\
\hline
\end{tabular}

Table 3. Anguilla rostrata. Frequency and intensity of occurrence of vaterite inclusions in otoliths of American eels from 3 rivers in Atlantic Canada; n: number of otoliths. ER: East River; CR: Castors River; FBB: Flat Bay Brook

\begin{tabular}{|lcccccc|}
\hline \multirow{2}{*}{ Site } & \multicolumn{3}{c}{ Frequency } & \multicolumn{3}{c|}{ Intensity (\%) } \\
& $\mathrm{n}$ & Mean & Range & Mean & Median & Range \\
\hline ER & 13 & 2.31 & $1-5$ & 1.35 & 0.37 & $0.08-4.89$ \\
FBB & 30 & 2.07 & $1-6$ & 4.81 & 0.14 & $0.05-37.43$ \\
CR & 20 & 1.85 & $1-5$ & 2.69 & 0.60 & $0.07-21.37$ \\
\hline
\end{tabular}

migratory eels. The frequency of occurrence of inclusions in vateritic otoliths did not vary significantly among MGs $\left(F_{1,61}=1.29, \mathrm{p}=0.26\right)$, nor did the intensity $\left(F_{1,54}=0.037, \mathrm{p}=0.85\right)$ after the exclusion of outliers.

Most $(47.6 \%)$ vateritic otoliths were found in eels from Flat Bay Brook, where they comprised $66.7 \%$ (column \%) of vateritic otoliths for MG 4 (Table 2). Although the mean percentage of freshwater residence (\%fwg) varied significantly among sites $\left(F_{2,159}=\right.$ 25.7, p < 0.001), ranging from $22.0 \%$ at Flat Bay Brook to $79.0 \%$ at Castors River, the prevalence of vateritic otoliths was not significantly influenced by the proportion of residence in freshwater (or, alternatively, in the estuary) $\left(F_{1,159}=0.49, \mathrm{p}=0.48\right)$. No significant interaction occurred between sites and vaterite prevalence $\left(F_{2,159}=0.33, \mathrm{p}=0.72\right)$.

The mean frequency of occurrence of vaterite inclusions did not differ among sites $\left(F_{2,60}=0.95, \mathrm{p}=0.39\right)$, nor did mean intensity $\left(F_{2,60}=0.25, \mathrm{p}=0.78\right)$ (Table 3$)$. Although 5 large intensity values from Flat Bay Brook and 2 large values from Castors River might be considered outliers, Levene's test for heterogeneity of variances on the transformed intensity values was nonsignificant $(F$-ratio $=0.59, \mathrm{p}=0.56)$. A more robust analysis of intensity (raw data) is by randomization ANOVA based on the sum of the absolute deviations from the grand mean (Edgington 1995), which supports the finding of no significant difference in mean intensities among sites $(\mathrm{n}=63, \mathrm{p}=0.33$, repetitions $=$ 5000).

\section{DISCUSSION}

The present study is the first to examine the prevalence, frequency of occurrence and intensity of vaterite inclusions in the aragonite otoliths of American eels Anguilla rostrata. Tzeng et al. (2007) confirmed the existence of vaterite in the otoliths of European eels A. anguilla and noted that the misidentification of vaterite may lead to serious misinterpretation of the inter-habitat migratory history of anguillid eels.

For an eel with a largely estuarine habitat residence history, $\mathrm{Sr}$ :Ca ratio values in aragonite were from 5.8 to 10.5 times greater than in vaterite. Tzeng et al. (2007) reported Sr:Ca ratio values from 7.1 to 7.4 times greater in aragonite than in vaterite for European eels with a saltwater history.

The prevalence of vaterite inclusions in American eels varied significantly among sites, from 21.3 to $58.8 \%$, as compared with $48 \%$ for European eels from Baltic sites (Tzeng et al. 2007). Although a marginally non-significant linear increase (of low effect size) was found in the prevalence of vateritic otoliths with increasing latitude, a non-linear trend was highly 
significant and of high effect size due to the high prevalence in Flat Bay Brook and higher prevalence values from the more northerly Newfoundland locations than from Nova Scotia.

The significant difference in vaterite prevalence among American eel MGs was driven by Flat Bay Brook, where $47.6 \%$ of eels with vateritic otoliths were found, of which $66.7 \%$ were from MG 4. MG 4 consists of inter-habitat migratory eels that first entered freshwater as juveniles after $\geq 1 \mathrm{yr}$ in the estuary followed by $1(+)$ periods of migration to the estuary and finally returning to the river before capture (Jessop et al. 2006). Stress may be an important factor in the prevalence of vateritic otoliths in cultured fish (Bowen et al. 1999, Sweeting et al. 2004). Environmental stress is generally considered greater at higher latitudes, and the American eels from Newfoundland are close to the northern limit of their distribution (Scott \& Scott 1988). The high prevalence of vateritic otoliths in eels from Flat Bay Brook may be partly due to the estuarine location of the sampling site, which is tidally saline, but may be totally freshwater at low tide during periods of higher discharge, such as after a heavy rainfall, or other high stress factors associated with the site. Fluctuating water temperatures and salinity have been proposed as factors affecting otolith crystalline growth (Tzeng et al. 2007), but this remains to be proved. However, the absence of any significant relation between the prevalence of vateritic otoliths and the proportion of residence in fresh- (or estuarine) water and the high proportion of vateritic otoliths in migratory eels suggest that it is not the proportion of residence time in any particular habitat but rather the process of inter-habitat movement that may influence the prevalence of vateritic otoliths. Given that eel mean age at migration increases with latitude and the number of inter-habitat movements increases with age, an increase in inter-habitat migration may occur with increasing latitude (Jessop et al. 2007), thus possibly resulting in a higher prevalence of vateritic otoliths at higher latitudes. Alternatively, an unknown site-specific factor may be responsible. Tzeng et al. (2007) found no difference in prevalence among habitats for European eels. It is premature to conclude that the prevalence of vateritic otoliths in American eels increases with latitude because of the limited otolith sample sizes, number of sites and latitudinal range examined to date, as well as the potentially confounding effect of habitat difference (estuarine, freshwater) among sites; further investigation is required to resolve this issue.

The substantial prevalence of vaterite inclusions in American eel otoliths requires that its presence be ascertained prior to analyzing otoliths for $\mathrm{Sr}$ :Ca ratios or other element compositions. As Tzeng et al. (2007) note, the presence of vaterite can be determined following etching with EDTA and viewing under reflected light, as also shown in the present study.

The frequency and intensity of vaterite inclusions in American eel otoliths did not differ significantly among sites. Most (83 to $92 \%$ ) otoliths with vaterite inclusions had few (1 to 6 ) inclusions of small ( $<5 \%$ of total otolith area) size, making it relatively easy to avoid those inclusions, once identified, when positioning electron microprobe or LA-ICPMS (laser ablation inductivelycoupled plasma mass spectrometry) transects. Of the otoliths that contained inclusions, 0 to $17 \%$ of otoliths from each site, particularly Flat Bay Brook, contained large (typically 15 to $37 \%$ ) quantities of vaterite that might be problematic when considering sample sizes for prospective otolith Sr:Ca ratio studies. However, even with such otoliths, suitable transects not containing vaterite could usually be found. The overall conclusion is that, although the prevalence of vaterite inclusions may vary substantially among sites, the frequency of occurrence and intensity of inclusions does not.

If small $(<5 \%$ of otolith area) vaterite inclusions are inadvertently included in an otolith $\mathrm{Sr}$ :Ca transect, the interpretation of that transect will vary depending upon whether the vaterite was deposited while the eel was in a saltwater or freshwater habitat and whether the surrounding aragonite has $\mathrm{Sr}: \mathrm{Ca}$ ratios typical of fresh- or saltwater habitat residence. Vaterite deposited while the eel is in a freshwater habitat tends to have very low, near zero, $\mathrm{Sr}$ :Ca ratio values, while vaterite deposited while the eel is in a saltwater habitat tends to have slightly higher $\mathrm{Sr}$ :Ca ratio values, typically in the mid- to lower ranges of freshwater $\mathrm{Sr}$ :Ca ratio values. If surrounded by a 'freshwater' $\mathrm{Sr}$ :Ca ratio signal, the low $\mathrm{Sr}$ :Ca ratio values typical of vaterite may go unnoticed because they are in the range of the freshwater signal. If the vaterite inclusion is surrounded by a 'saltwater' signal, it might be interpreted as an interhabitat movement to freshwater and return to saltwater, thus overestimating the \%fwg and the frequency of inter-habitat movement. The overestimate of the \%fwg caused by a small vaterite inclusion might be biologically trivial, but the overestimation of the frequency of inter-habitat movement may be more serious due to the low frequency typical of inter-habitat movements (Jessop et al. 2008).

The much lower $\mathrm{Sr}$ concentrations in vaterite than in aragonite result from differences in their crystalline structure (Tomás \& Geffen 2003, Tzeng et al. 2007). Sr has a relatively large ionic radius and is preferentially excluded relative to elements such as $\mathrm{Na}, \mathrm{Mg}$ and $\mathrm{Mn}$ during the formation of vaterite. Ca also preferentially enters the aragonite lattice relative to the vaterite lattice and thus is more easily chelated from vaterite when the otolith is etched with EDTA. This leaves 
more organic matrix, which reflects light poorly, in vaterite than in aragonite and thus makes the vaterite structure appear dark when viewed by microscope under reflected light (Tzeng et al. 2007).

The effect of vateritic otoliths on fish behaviour and survival are uncertain. Totally or highly vateritic otoliths impair auditory sensitivity (Oxman et al. 2007), thereby potentially affecting fish behaviour (e.g. ability to avoid predators or locate prey) in ways that could decrease survival. Some adult fish of many species, including American and European eels, contain vateritic otoliths, thereby implying that their presence may not always be detrimental. Oxman et al. (2007) suggest that fish may have some ability to compensate for the hearing loss associated with vateritic otoliths or that the hearing loss may be of little biological consequence. Vateritic otoliths are much more prevalent in cultured than in wild fish (Bowen et al. 1999, Sweeting et al. 2004), suggesting that eels that are cultured before release into the wild in stocking programs may acquire an increased prevalence of vateritic otoliths, with possible negative consequences for survival. However, Tzeng et al. (2007) found similar proportions of vateritic otoliths in wild and in restocked European eels from Baltic waters. The restocked eels were purchased as elvers and had been held in ponds for only a short time (days to weeks) before being released to the wild.

Analyses of anguillid otolith $\mathrm{Sr}$ :Ca ratio transects have commonly been used to evaluate their residence and migratory history between habitats of different salinity (Daverat et al. 2006, Jessop et al. 2008). Replicate, closely spaced Sr:Ca ratio transects produced close estimates of the proportion of freshwater residence for eels of largely estuarine residence, as required for the method to be useful. Although suitable transect paths for microchemical analysis may be found in highly vateritic otoliths, some otoliths may be entirely composed of vaterite and unsuitable for use. When an Sr:Ca ratio transect crossed vaterite inclusions, the proportion of freshwater residence was greatly overestimated. Fortunately, the presence of vaterite inclusions in otoliths is readily determined and their intensity in American eel otoliths is typically small, reducing the potential bias in estimating habitat residence period; but if overlooked, the frequency of inter-habitat migration can be overestimated. Vaterite inclusions need not be an impediment to the use of microchemical analyses of American eel otoliths, but their presence should be identified and avoided if habitat residence and migratory history are not to be misidentified.

Acknowledgements. We thank M. Feigenbaum of South Shore Trading Ltd. for the Newfoundland eel samples, D. Cairns for the map, and the National Science Council, ROC, for financial support (NSC 95-2313-B-002-027).

\section{LITERATURE CITED}

Bowen CA II, Bronte CR, Argyle RL, Adams JV, Johnson JE (1999) Vateritic sagitta in wild and stocked lake trout: applicability to stock origin. Trans Am Fish Soc 128: 929-938

$>$ Brown R, Severin KP (1999) Elemental distribution within polymorphic inconnu (Stenodus leucichthys) otoliths is affected by crystal structure. Can J Fish Aquat Sci 56: 1898-1903

> Campana SE (1999) Chemistry and composition of fish otoliths: pathways, mechanisms and applications. Mar Ecol Prog Ser 188:263-297

Cohen J (1988) Statistical power analysis for the behavioral sciences, 2nd edn. L. Erlbaum, Hillsdale, NJ

$>$ Daverat F, Limburg KE, Thibault I, Shiao JC and others (2006) Phenotypic plasticity of habitat use by three temperate eel species, Anguilla anguilla, A. japonica and A. rostrata. Mar Ecol Prog Ser 308:231-241

$>$ Degens ET, Deuser WG, Haedrich RL (1969) Molecular structure and composition of fish otoliths. Mar Biol 2:105-113

Edgington ES (1995) Randomization tests, 3rd edn. Dekker, New York

Elsdon TS, Gillanders BM (2003) Reconstructing migratory patterns of fish based on environmental influences on otolith chemistry. Rev Fish Biol Fish 13:219-235

Gauldie RW (1986) Vaterite otoliths from chinook salmon (Oncorhynchus tshawytscha). NZ J Mar Freshw Res 20: 209-217

Jessop BM, Shiao JC, lizuka Y, Tzeng WN (2002) Migratory behaviour and habitat use by American eels Anguilla rostrata as revealed by otolith microchemistry. Mar Ecol Prog Ser 233:217-229

Jessop BM, Shiao JC, Iizuka Y, Tzeng WN (2006) Migration of juvenile American eels Anguilla rostrata between freshwater and estuary, as revealed by otolith microchemistry. Mar Ecol Prog Ser 310:219-233

Jessop BM, Shiao JC, Iizuka Y, Tzeng WN (2007) Effects of inter-habitat migration on the evaluation of growth rate and habitat residence of American eels Anguilla rostrata. Mar Ecol Prog Ser 342:255-263

Jessop BM, Cairns DK, Thibault I, Tzeng WN (2008) Life history of American eel Anguilla rostrata: new insights from otolith microchemistry. Aquat Biol 1:205-216

> Kalish JM (1989) Otolith microchemistry: validation of the effects of physiology, age and environment on otolith composition. J Exp Mar Biol Ecol 132:151-178

> Melancon S, Fryer BJ, Ludsin SA, Gagnon JE, Yang Z (2005) Effects of crystal structure on the uptake of metals by lake trout (Salvelinus namaycush) otoliths. Can J Fish Aquat Sci 62:2609-2619

> Oxman DS, Barnett-Johnson R, Smith ME, Coffin A, Miller DL, Josephson R, Popper AN (2007) The effect of vaterite deposition on sound reception, otolith morphology, and inner ear sensory epithelia in hatchery-reared Chinook salmon (Oncorhynchus tshawytscha). Can J Fish Aquat Sci 64:1469-1478

Pannella G (1971) Fish otoliths: daily growth layers and periodical patterns. Science 173:1124-1127

Scott WB, Scott MG (1988) Atlantic fishes of Canada. Can Bull Fish Aquat Sci 219

Sokal RS, Rohlf FJ (1981) Biometry, 2nd edn. WH Freeman, New York

Sweeting RM, Beamish RJ, Neville CM (2004) Crystaline otoliths in teleosts: comparison between hatchery and wild coho salmon (Oncorhynchus kisutch) in the Strait of Georgia. Rev Fish Biol Fish 14:361-369 
Tomás J, Geffen AJ (2003) Morphometry and composition of aragonite and vaterite otoliths of deformed laboratory reared juvenile herring from two populations. J Fish Biol 63:1383-1401

Tzeng WN (1996) Effects of salinity and ontogenetic movements on strontium:calcium ratios in the otoliths of the Japanese eel Anguilla japonica Temminck and Schlegel. J Exp Mar Biol Ecol 199:111-122

Tzeng WN, Severin KP, Wickström H (1997) Use of otolith microchemistry to investigate the environmental history of European eel Anguilla anguilla. Mar Ecol

Editorial responsibility: Asbjørn Vøllestad, Oslo, Norway
Prog Ser 149:73-81

Tzeng WN, Shiao JC, Iizuka Y (2002) Use of otolith Sr:Ca ratios to study the riverine migratory behaviours of Japanese eel (Anguilla japonica). Mar Ecol Prog Ser 245: 213-221

Tzeng WN, Chang CW, Wang CH, Shiao JC and others (2007) Misidentification of the migratory history of anguillid eels by $\mathrm{Sr} / \mathrm{Ca}$ ratios of vaterite otoliths. Mar Ecol Prog Ser 348: 285-295

Wilkinson L, Blank G, Gruber C (1996) Desktop data analysis with SYSTAT. Prentice Hall, NJ

Submitted: January 15, 2008; Accepted: April 9, 2008 Proofs received from author(s): May 15, 2008 